Димони Т. М. Проблема социального лидерства и социального конфликта в СССР в трудах ученых Русского Зарубежья 1950-1970-х годов / Т. М. Димони // Научный диалог. 2020. 一 № 2. - C. 333-352. - DOI: 10.24224/2227-1295-2020-2-333-352.

Dimoni, T. M. (2020). Problem of Social Leadership and Social Conflict in USSR in Works of Scientists of Russian Emigre of 1950s and 1970s. Nauchnyi dialog, 2: 333-352. DOI: 10.24224/2227-1295-2020-2-333-352. (In Russ.).

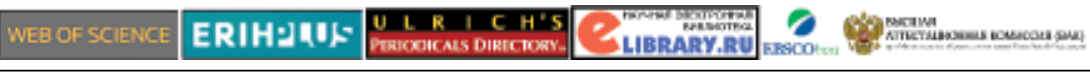

\title{
ПРОБЛЕМА СОЦИАЛЬНОГО ЛИДЕРСТВА
}

\section{И СОЦИАЛЬНОГО КОНФЛИКТА В СССР В ТРУДАХ УЧЕНЫХ РУССКОГО ЗАРУБЕЖЬЯ 1950-1970-Х ГОДОВ ${ }^{1}$}

(C) Димони Татьяна Михайловна (2020), orcid.org/0000-0002-9049-1469, ResearcherID AAF-4638-2019, SPIN 4394-1937, доктор исторических наук, доцент, федеральное государственное бюджетное образовательное учреждение высшего образования «Вологодский государственный университет» (Вологда, Россия), dimonitm@yandex.ru.

В статье рассматривается вопрос об осмыслении учеными, общественными деятелями Русского Зарубежья социальных отношений в СССР 1950-1970-х годов. Новизна работы состоит в выборе источников исследования - статей и книг деятелей Русского Зарубежья. Автор подчеркивает, что основная часть идей рассмотренных авторов недостаточно представлена в научном обороте. Отмечается, что родоначальниками исследований советского общества были ученые Мюнхенского института изучения истории и культуры СССР, которые в 1957 году провели крупную международную конференцию «Современное советское общество». В статье сделан вывод, что доклады конференции о многочленности советского общества, наличии серьезной правовой и экономической дифференциации, зарождении новых прогрессивных классов (инженерно-технической интеллигенции) заложили базис для продвижения исследований о российском обществе. По мнению автора, в конце 1960-х годов данное направление активно культивировалось советскими диссидентами, эмигрировавшими на Запад, и близкими к ним соратниками, остававшимися в СССР (А. А. Амальрик, К. Буржуадемов, С. С. Малевский-Малевич, В.В.Белоцерковский). Выполненный обзор историографии Русского Зарубежья позволяет создать платформу для размышлений о социальных силах советского общества, движущих мотивах их деятельности и борьбе за место в классовой иерархии.

Ключевые слова: СССР; Русское Зарубежье; классовый конфрликт; классовое лидерство.

1 Исследование выполнено при финансовой поддержке РФФИ, проект 18-09-00184 «Социальная революция в советской России: предпосылки, этапы, итоги». 


\section{1. Постановка проблемы классовых взаимоотношений в историографии}

Проблема взаимоотношений классов в Советском Союзе остается одной из наименее исследованных в историографии социальных отношений. Если уйти от неопределенности с самой классовой градацией (сколько на самом деле классов было в СССР?), вне сферы внимания историков оставались также проблемы борьбы классов за влияние и перемещения в социальной иерархии, которые присутствуют в любом развитом обществе.

В советской историографии, согласно общепринятой в тот период теории, утверждалось, что господствующим классом в советской системе, ее гегемоном является пролетариат, остальные же классы занимают второстепенную позицию. При этом происходит постепенное сближение рабочего класса и колхозного крестьянства, а также рабоче-крестьянской интеллигенции. Оговаривалось также, что борьба между классами отсутствует, так как они не являются антагонистическими [Островский, 1967; Рабочий класс ..., 1975; Сенявский, 1966; Ярославский, 1939]. Зарубежные исследователи, как правило, улавливали серьезный уровень материальной дифференциации населения в Советском Союзе, подчеркивали существование бедных или стесненных в средствах групп и обладающих большими привилегиями высших управленцев [Parry, 1966; Matthews, 1972; Matthews, 1982; Matthews, 1978]. Основной креативной идеей, высказанной в зарубежной историографии по поводу классов в СССР, было мнение о формировании в советский период «нового класса», находящегося у власти, партийной номенклатуры. Впервые эту идею сформулировал М. Джилас в середине 1950-х годов [Джилас, 1957] Почти одновременно с М. Джиласом данное мнение высказал А. Авторханов [Авторханов, 1959], позднее эту концепцию принял и развил в своих произведениях М. Восленский [Voslenskii, 1984; Восленский, 1991]. Пожалуй, все же главным «мозговым центром» по осмыслению классовой дифференциации советского общества, взаимоотношений классов и их иерархии стали эмигранты из СССР, знавшие советскую жизнь изнутри и обладавшие изрядными аналитическими способностями. Ряд их работ появился за рубежом в тот период, когда они только выехали из СССР или даже накануне эмиграции из Советского Союза. Находясь в эмиграции, многие из них продолжили изучение советского общества, работая в научных и образовательных центрах.

\section{2. Осмысление проблем социальных отношений в СССР сотрудниками Мюнхенского института изучения истории и культуры СССР}

Одной из первых попыток осмысления взаимоотношений классов в СССР стала работа Мюнхенского института по изучению истории и 
культуры СССР. История этого учреждения была неоднократно описана в историографии. Только в последнее время его деятельность привлекала внимание таких авторов, как Е. В. Кодин, А. В. Попов и др. [Кодин, 2013, c. 148 - 167; Попов, 2004, с. 54-71; Константинов, 2002, с. 133-144; Константинов, 1983, с. 13-21; Константинов, 1997, с. 56-85; O’Connel, 1990]. Так, историком А. В. Поповым описаны материалы созданного в Государственном архиве РФ фонда первого директора Института Б. А. Троицкого (в разное время он жил под фамилиями Норманна, Нарейкиса, Яковлева). Частично взгляды сотрудников Мюнхенского института по изучению истории и культуры СССР были описаны Ю. Н. Егоровым [Егоров, 2009а; Егоров, 2009б]. Институт был создан в 1950 году, по словам его основателей, как «свободная корпорация научных работников и специалистов, эмигрантов из СССР, ставящая своей целью всестороннее изучение СССР и ознакомление с результатами исследований научно-исследовательских учреждений и общественности свободного мира» [Там же, с. 3-7]. Данная трактовка расходится с сообщениями других источников. Например, М. Назаров, рассказывая о возникновении Мюнхенского института, указывает, что он появился в начале «холодной войны» в рамках американской «технической и материальной поддержки антибольшевистских сил в эмиграции и в СССР», и, как правило, ученые, сотрудничавшие с институтом, были связаны также и с Гарвардским университетом [Назаров, 1992, c. 369].

Учредителями Мюнхенского института по изучению истории и культуры СССР стали 8 эмигрантов из страны, оказавшиеся после войны в западной части Германии: М. А. Алдан (Г. А. Нерянин), К. Г. Криптон (Молодецкий), А. А. Кунта (Авторханов), В. П. Марченко, Ю. П. Ниман (Боголепов), А. П. Филипов, К. Ф. Штеппа и Б. А. Яковлев [Назаров, 1992, с. 3]. Яковлев писал: «Все мы выступали под нашими псевдонимами, потому что хорошо знали, что у советских спецслужб длинные руки» [Бузукашвили, 2012, с. 31-37]. Директором Института стал Б. А. Яковлев. Его биография уже довольно хорошо известна. С началом Великой Отечественной войны он ушел на фронт, через несколько месяцев попал в плен. В 1943 году Яковлев (тогда - Нарейкис) оказался в распоряжении бывшего генерала А. А. Власова, стал работать редактором военной газеты «За Родину». После войны американские власти дали Яковлеву право остаться в Мюнхене [Кодин, 2013, с. 148-167]. М. А. Алдан (Нерянин Андрей Георгиевич) (1904-1957) был полковником Советской армии, участником Гражданской войны. С началом войны был назначен начальником оперативного отдела штаба 20-й армии. С 1942 года был в немецком 
плену, в 1944 году вступил в Русскую освободительную армию генерала Власова [Александров, 2001, с. 144-145]. Криптон (настоящая фамилия Молодецкий) Константин Георгиевич родился в 1902 году в Петербурге. С 1930 года состоял доцентом в институте гражданского воздушного флота (институт входил в систему Комакадемии) [Архив ...]. В 1953 году исполнительным комитетом по изучению Советского Союза в США была выпушена книга К. Криптона (Молодецкого) «The Northern Sea Route, its place in Russian economic history before 1917», а в 1956 году издана вторая книга этого исследования, посвященная работам послереволюционного периода [Летопись ..., 1957, с. 4]. В 1942 году К. Молодецкий был эвакуирован на Северный Кавказ [Криптон, 1952, с. 225], где попал в оккупацию, а затем в Германию. В 1948 году получил работу в Германии «у американцев» [Толстой]. А. А. Кунта (Авторханов Абдурахман Генасович) (1908-1997) родился в ауле близ Грозного. В 1937 году окончил Институт красной профессуры в Москве по специальности «русская история». Партийный работник в Москве и Чечне. В 1938 году был арестован, пять лет отсидел в московских тюрьмах. Не воевал, перешёл линию фронта в 1943 году, будучи штатским, был депортирован в Германию. После войны преподавал в Русском институте армии США, был одним из организаторов радиостанции «Свобода», защитил диссертацию в Германии, получил степень доктора политических наук [Авторханов, 1983].

Таким образом, большинство «отцов-основателей» Мюнхенского института являлись людьми образованными, работавшими в довоенное время в СССР в научных структурах или на высших военных должностях. Все они при разных обстоятельствах в период Великой Отечественной войны добровольно перешли на сторону противника, часть из них принимала участие в военных действиях против Советской армии. Опыт довоенной жизни в СССР в сочетании с возможностями пользоваться достижениями обществоведческих наук Западного мира и неплохое финансирование создавали для сотрудников Института по изучению СССР уникальную ситуацию получения нового знания по многим вопросам советской жизни. В условиях, когда в СССР уже сложился определенный канон в описании общества, исследования Мюнхенского института серьезно продвигали в осмыслении вопросов экономического, социального и политического устройства страны.

Основной задачей Институт считал изучение послевоенного облика советского общества, что обусловило отчасти новую для мировой советологии научную проблематику.

Уже на 1-й конференции научных работников-эмигрантов, состоявшейся в Мюнхене в январе 1951 года, были заслушаны доклады А. П. Фи- 
липпова «Свобода и творчество в области советской науки и философии», К. Ф. Лагодина (Штеппа) «Советская система управления массами и ее психологические последствия», доклад А. Авторханова «Положение исторической науки в СССР». В этом же году были выпущены книги П. Л. Кованьковского «Финансы СССР во вторую мировую войну», Б. Микорского «Разрушение культурно-исторических памятников в Киеве в 1934 1936 гг.», Г. Сааруни «Борьба армянской церкви против большевизма», П. Галина «Как производились переписи населения в СССР», Г. Шульца «Санитарная и противоэпидемическая работа в СССР», Л. Ржевского «Язык и тоталитаризм», В. Гречко «Коммунистическое воспитание в СССР». В последующие годы тематика изданий охватывала проблемы демографии населения СССР, развития культуры, особенно литературы, религиозной политики.

В 1958 году Институт по изучению СССР в Мюнхене провел конференцию, посвященную современному советскому обществу. На открытии выступил директор института В. С. Мерцалов, который пояснил, что речь на конференции планируется вести о движущих силах и тенденциях развития советского общества. Кроме того, В. С. Мерцалов говорил о трудности задач, которые ставили перед собой участники конференции, а также о том, что постановка этих задач была вызвана, во-первых, особой, очень сложной политикой советской власти, во-вторых, пропагандистскими декларациями власти, в-третьих, тенденциозным отражением жизненных условий и других социальных факторов и явлений в советской печати, литературе и искусстве. Также В. С. Мерцалов нацелил участников на ведение исключительно научной дискуссии: «Советская история и советская действительность, — сказал он, - полны примеров очень сурового, жестокого отношения к человеку, несправедливостей и попрания человеческих прав. Трудно, поэтому, удержаться от привнесения эмоциональной окраски при оценке тех или иных явлений советской истории и советской действительности. Я, однако, полагаю, что не наше дело выносить моральную оценку всему этому, но наше дело дать научную оценку» [Х конференция ..., 1958, с. 6].

На конференции были заслушаны пять крупных докладов: профессоpa, доктора В. С. Сукенницкого «Социальная структура советского общества», профессора А. А. Авторханова «Господствующий класс в СССР», Г. Ф. Ахминова «Советская интеллигенция», М. Дюэр «Рабочий класс в СССР», В. С. Мерцалова «К вопросу о положении крестьянства в СССР». Каждый доклад подробно обсуждался участниками конференции. Все материалы были опубликованы в специальном сборнике по итогам конференции [Х конференция ..., 1958]. 
Первое заседание началось с доклада В. С. Сукенницкого о социальной структуре советского общества. Докладчик поставил цель - «проследить его изменения за последние 40 лет». Основная идея доклада состояла в описании дифференциации советского общества, была дана характеристика его основных классов (употреблялся именно такой термин): рабочих, колхозников, «заключенных в лагерях», «нового правящего класса», состоящего из партии, специалистов, бюрократии и интеллигенции. Одним из наиболее продуктивных было рассуждение о «новом правящем классе» и праве собственности в СССР. Профессор В. С. Сукенницкий обратил внимание на то, что основным преимуществом чччччправ собственника является право распоряжаться собственностью. В том числе, отметил он, и при так называемой «общественной собственности» имеется собственник (по мнению докладчика, это коммунистическая партия, которая слилась с «аппаратом»). Конечно, продолжал он, тресты, заводы или колхозы не стали частной собственностью юридически, но фактически были порученными им «хозяйствами», в которых они распоряжались более или менее по своему усмотрению. Новые «собственники» отдавали приказания «своим» служащим, рабочим или колхозникам и «те им повиновались». Они в границах «планов», инструкций и приказов «сверху» решали судьбы вверенных им средств производства и их продукции. Таким образом, делал вывод докладчик, в СССР возникла не только особая группа людей с «хозяйскими» функциями, у них стали складываться обычаи, иногда оформленные в советских законах («номенклатурные работники»), формировалась групповая психология и навыки. Новый общественный класс начал обособляться от других общественных групп. Немаловажным для нового класса был вопрос наследственности и преемственности. В целом, подводил итог Сукенницкий, новый класс в СССР сосредоточил в своих руках могущество, которого не имел никакой другой общественный класс в истории человечества, так как он монополизировал власть не только экономическую, но и политическую [Там же, с. 39-41].

Схожими по сути были и идеи доклада А. А. Авторханова «Господствующий класс в СССР», прозвучавшего без перерыва после доклада проф. В. Сукенницкого. Обсуждались оба доклада вместе. Ряд участников конференции (например, профессор С. И. Утехин из Англии) похвалил доклад В. Сукенницкого за пионерский характер, однако покритиковал за сомнительное определение класса в советском обществе, а также за отсутствие серьезных доказательств складывания нового правящего класса [Там же, с. 63]. Употребление термина класс посчитал также неуместным профессор П. Д. Уайльс (Англия). По его мнению, в марксистском понимании - 
это не класс, так как он не находится ни в каком специальном отношении к собственности: «В этом смысле советское притязание на бесклассовость совершенно правильно» [Там же, с. 74]. Профессор И. А. Курганов (США) возразил докладчикам, что в СССР нет класса, который угнетал бы другие классы, а есть партия, которая угнетает весь народ [Там же, с. 67]. Профессор Б. Рихтгофен поприветствовал работы института, «сотрудники которого, принадлежащие по своему происхождению к порабощенным советским народам, более, чем кто-либо другой, знает о действительном положении в СССР» [Там же, с. 68]. Профессор А. В. Юрченко, откликаясь на доклад А. А. Авторханова, отметил, что КПСС ищет новую идеологическую основу, и связана она «с ощущением своей великодержавности, своей миссии в мире уже не как носителей только идеи мировой революции, но как правящего слоя новой империи» [Там же, с. 74].

Очень важные мысли прозвучали в докладе Г. Ф. Ахминова «Советская интеллигенция», посвященном части интеллигенции СССР — технической интеллигенции. По мнению Г. Ф. Ахминова, положение ее принципиально изменилось с 1936-1937 годов, когда основные массы выдвиженцев уже получили образование и были заложены основы современной промышленности. Анализируя положение технической интеллигенции, докладчик пришел к выводу, что члены этой группы представляют собой потенциальных могильщиков коммунистической диктатуры, потому что человек, который выполняет функции частного предпринимателя, в связи с провозглашением принципа рентабельности обязан работать так, «как будто» он является частным предпринимателем, и очень легко может прийти к мысли, что было бы хорошо стать частным предпринимателем. С 1950 года, по мысли докладчика, выдвинувшего идею возникновения могильщиков коммунизма в лице технической интеллигенции, он наблюдал усиливавшуюся в СССР тенденцию к благосостоянию и «тайному капитализму», то есть черному рынку. Г. Ф. Ахминов описал идеологию технической интеллигенции СССР. По его мнению, задачу разработки ее идеологии взял на себя «самый яркий представитель этой группы населения, председатель Государственной плановой комиссии Н. Вознесенский. В 1947 году он опубликовал свою книгу “Экономика СССР в период Отечественной войны”» [Вознесенский, 1947]. По мнению Г. Ф. Ахминова, краеугольным камнем идеологии Н. Вознесенского стало требование «признать принцип материальной заинтересованности основным стимулом в развитии народного хозяйства страны» [Х конференция ..., 1958, с. 99]. Несмотря на то, что Вознесенский был ликвидирован, закон стоимости победил. И это была ревизия одного из основных положений, которые Сталин завещал своим 
наследникам накануне XIX съезда. Теперь техническая интеллигенция проявляет тенденцию к «обуржуазиванию» и выдвигает требование вести хозяйство на основе рынка.

Обсуждение доклада Ахминова продемонстрировало непонимание большинством участников конференции его идей. М. А. Исаакян дискутировал об употреблении Ахминовым термина интеллигенция. Он напомнил, что «интеллигенция в подлинном смысле слова» обладает специальными знаниями, а также устойчивыми моральными принципами [Там же, c. 109-110]. Профессор Е. А. Гловинский напомнил о схожей теории революции менеджеров Бернгейма [Там же, с. 110-111]. Доктор П. Шейберт подчеркнул, что понятие «интеллигенция» родилось в определенной исторической обстановке и связано с определенным историческим периодом. Он не согласился с Ахминовым в употреблении термина интеллигенция и призвал называть тех, о ком он говорил, специилистами, так как они явно не были носителями культуры [Там же, с. 113].

Доклады М. Дюэр о советских рабочих и В. С. Мерцалова о крестьянстве были менее новаторскими. М. Дюэр высказала мнение, что единого рабочего класса в СССР не существует, так как он многонационален. Кроме того, она проанализировала этапы развития рабочего законодательства в СССР, подчеркнув его жесткость в 1940-1958 годах [Там же, с. 124-143]. В. С. Мерцалов охарактеризовал численность крестьянства, подчеркнув его неполноправность и бедственное положение [Там же, c. $144-172]$.

Линии на исследование советского общества Мюнхенский институт по изучению истории и культуры СССР придерживался весь период своего активного существования. В 1955 году была издана работа А. П. Филиппова «Научный социализм и наука об обществе» [Филиппов, 1955], в 1956 книги П. А. Кованьковского «Бюджет СССР (историко-критический об3ор)» [Кованьковский, 1956], Г. Ф. Ахминова «Объективное сопротивление в СССР» [Ахминов, 1956], Е. Сербина «Политические настроения в советской армии в послесталинский период» [Сербин, 1956]; в 1959 — работы В. П. Марченко «Основные черты хозяйства послесталинской эпохи» [Марченко, 1959], А. Д. Билимовича «Эра пятилетних планов в хозяйстве СССР» [Билимович, 1959]. Отдельное внимание уделялось исследователями Мюнхенского института советской молодежи. Так, в 1960 году была опубликована книга Д. Бурга, посвященная оппозиционным настроениям советской молодежи второй половины 1950-х годов [Бург, 1960]. По мнению автора данной работы, в молодежной, прежде всего студенческой, среде, находилась в процессе выработки революционная идеология. Она 
была вызвана стремлением к созданию демократически контролируемой власти, что постоянно вызывало репрессии в отношении наиболее оппозиционных студентов. В 1962 году в Мюнхене состоялась крупная научная конференция, где обсуждались проблемы советской молодежи [Молодежь ..., 1962]. Одним из докладчиков на данной конференции выступил Г. Ф. Ахминов с темой «Стремления и чаяния советской молодежи». Доклад этого автора привлек большое внимание, его текст (машинопись) сохранился в фондах аппарата ЦК КПСС [Российский ...]. По мнению Г. Ф. Ахминова, в СССР существовало как минимум 6 классов (по разделению функций в общественном производстве): партийный аппарат (профессиональные партийные работники и карательный аппарат), государственный аппарат (в том числе армия), техническая интеллигенция, работники торговли и общественных услуг, рабочие и колхозники. Выработка новых идеологических взглядов, отмечал Г. Ф. Ахминов, прежде всего происходит в молодой части класса технической интеллигенции. Среди новых идеологических веяний он отмечал гуманизм (в либеральном варианте), патриотизм (с чертами космополитизма и национализма), индивидуализм (с вниманием к правам человека).

\section{3. Работа Русского Зарубежья по осмыслению проблем социально- классового лидерства в СССР в 1960—1970-е годы}

Серьезный импульс размышлениям ученых и общественных деятелей Русского Зарубежья о социальных силах советского общества дала работа А. А. Амальрика «Просуществует ли Советский Союз до 1984 года?» [Амальрик, 1969], изданная в Амстердаме в 1969 году фондом имени А. Герцена. Известный советский диссидент был вынужден эмигрировать из СССР в 1976 году. А. А. Амальрик сравнивает советское общество 1960-х годов со своего рода трёхслойным пирогом - с правящим бюрократическим верхним слоем; средним слоем, который он называет «средним классом», или «классом специалистов»; и наиболее многочисленным «нижним слоем» - рабочими, колхозниками, мелкими служащими, обслуживающим персоналом и т. д. Рассматривая социальные силы в СССР, А. А. Амальрик отмечал, что с 1952 по 1957 годы в стране происходила «верхушечная революция», однако бюрократическая элита, по его мнению, была достаточно пассивной. В то же время «верхушечная революция» расшатала монолитное общество и положила начало появлению новой, независимой от правительства силы. А. А. Амальрик назвал ее «культурная оппозиция» (он включил в нее ряд писателей, других представителей культуры, которые «заговорили по-новому»). Притом что правящий режим ста- 
рался бороться с данной оппозицией, победу ему одержать не удалось, из недр «культурной оппозиции» вышла сила, которая составила оппозицию уже в сфере политики и идеологии (самиздат). А. А. Амальрик описывал формирование трех идеологий оппозиции: «подлинного марксизма-ленинизма», «христианской идеологии» и «либеральной идеологии».

Поиск наиболее серьезной силы социальных изменений привел А. А. Амальрика к мысли, что это «средний класс» («класс специалистов»). По мнению А. А. Амальрика, он складывался в СССР в 19501960-е годы и включал в себя группы лиц со средними доходами, обладающих профессиями, требующими значительной подготовки. Класс этот, по мнению исследователя, был довольно многочисленным, на него опиралась власть в развитии экономики и науки. Эта социальная группа нуждалась в «известной прагматической и интеллектуальной свободе», а также в правопорядке. А. А. Амальрик отмечал, что данный класс начинал уже осознавать свое единство и заявлять о себе. В качестве доказательства А. А. Амальрик проанализировал социальный состав «подписантов» под разными коллективными и индивидуальными письмами диссидентов. Всего в его подсчеты попали 738 человек, из них учеными были $45 \%$; деятелями искусства - $22 \%$; инженерами и техниками $13 \%$; издательскими работниками, учителями, врачами, юристами $9 \%$; рабочими $-6 \%$; студентами $-5 \%$. В то же время А. А. Амальрик довольно пессимистично относится к прогрессивным возможностям «класса специалистов» (за что довольно большая часть эмиграции заподозрила А. А. Амальрика в сотрудничестве с КГБ). Проблема «среднего класса», как отмечал Амальрик, состоит в «очиновленности» мышления и пассивности самой интеллектуально независимой части. Исследователь приходит к выводу о том, что рост «среднего класса» и его самоорганизация напрямую повлияет на советское общество и покажет, сможет ли оно перестроиться быстрым и безболезненным путем. Одну из опасностей для «среднего класса» представляли, по мнению А. А. Амальрика, «низшие классы». Их А. А. Амальрик оценивал как деклассированных и регрессивных. Он отмечает, что «пролетаризация» деревни породила «странный класс» - «не крестьян и не рабочих, с двойной психологией собственников своих микрохозяйств и батраков гигантского анонимного предприятия» [Амальрик, 1969, с. 33]. Вместе с тем А. А. Амальрик отмечает и деградацию горожан, связанную с колоссальным отливом крестьянской массы из деревни. Этот тип горожанина, отмечал он, с большим трудом обретает новые быт и культуру, чувствует себя очень неуютно, отличается запуганностью и агрессивностью. 
Размышления А. А. Амальрика оказали большое влияние на осмысление социальной жизни советского общества. Советский диссидент В. В. Сокирко (писал под псевдонимом К. Буржуадемов), который, хотя и не эмигрировал, но работал в одном направлении с исследователями советского общества, находившимися в эмиграции, уделил большое вниманию развитию идей А. Амальрика в плане исследования рождавшихся в советском обществе идеологий и социальных классов [Буржуадемов, 1974]. Довольно развернутую картину советского общества начала 1970-х годов дал публицист, художник и общественный деятель С. Малевский-Малевич в книге «СССР сегодня и завтра», изданной в Париже в 1972 году [Малевский-Малевич, 1972]. Книга была подготовлена по материалам впечатлений от поездки в СССР. В конце 1970-х годов в Западной Германии вышла работа «Свобода, власть и собственность» журналиста и правозащитника В. Белоцерковского, эмигрировавшего из СССР в 1972 году [Белоцерковский, 1977]. Довольно много внимания в книге уделено описанию советской классовой системы, чему посвящен специальный раздел «Миф о трех классах в СССР».

Практически все авторы, анализирующие развитие социальной структуры СССР, отмечали ее более сложный, чем официально признаваемый, каркас. В. В. Сокирко (К. Буржуадемов) отмечал, что социалистическое общество не является монолитным, оно обладает признаками классовой разнородности, причем социальные низы противостоят социальным верхам. В целом В. В. Сокирко приходил к выводу о существовании в советском обществе 1970-х годов двух пар основных классов: двух старых классов, среди которых (1) неразвитые, малоквалифицированные, покорные рабочие и (2) высшее руководство страны, буржуазное по характеру, феодальное по методам власти; и двух новых классов, состоящих из (1) буржуазно настроенной рабочей аристократии и технической интеллигенции и (2) производственного и научного руководства [Буржуадемов, 1974, c. 181]. Мнение В. В. Белоцерковского обладало своей спецификой, поскольку в качестве исходной точки анализа он избрал утверждение о том, что в СССР сложилась система государственного капитализма. По мнению В. Белоцерковского, гораздо продуктивнее, чем делить общество на классы, было разбить его на ряд слоев по общности условий жизни и работы, психологии и социально-политических чаяний. В. Белоцерковский различает шесть таких слоев: 1) партийная и технократическая олигархия; 2) научная интеллигенция (точные науки); 3) гуманитарная интеллигенция; 4) инженеры, техники, рабочие и служащие промышленности (инженерно-рабочий слой); 5) крестьянство; 6) работники торговли и обслужи- 
вания, кустари, мелкие служащие, отчасти строители (услужающий слой) [Белоцерковский, 1977, с. 53].

Практически общим местом всех публицистов было мнение о существовании в СССР привилегированного слоя. По мнению В. В. Сокирко, в советском обществе зародились и растут как новые буржуазные классы, так и буржуазно-демократическая идеология. Этот автор считал, что руководство страны 1970-х годов являлось представителем старого феодального правящего класса. Поэтому В. В. Сокрико довольно много размышлял над вопросом: проявит ли оно волю и инициативу по перерождению в новый класс правящей крупной буржуазии? Логика его размышлений состояла в том, что «правящий класс» в условиях внешней экономической конкуренции неизбежно будет вынужден проводить реформы, при этом самые удачные будут двигать страну по капиталистическому пути (среди удачных В. В. Сокирко называет хозрасчет на предприятиях, введение понятия прибыли, гибкие цены, меняющиеся планы и др.). Таким образом, делает вывод В. В. Сокирко, буржуазно-демократическим развитием охвачены как низы общества, так и его верхние слои. Представители буржуазных тенденций как бы смыкаются между собой (рабочая аристократия и нижнее звено правящего класса) [Буржуадемов, 1974, с. 175]. С. Малевский-Малевич среди серьезных достижений советской власти в области социальной организации отметил складывание довольно большого слоя привилегированных (классы привилегированных высшего разряда, среднего и низшего). Среди привилегированных высшего разряда (новый социальный класс) Малевский-Малевич называл тех, кто имел квартиры, дачи, машины с шофером, хорошую одежду. По подсчетам посольств ряда стран, на которые опирался автор, доля «привилегированных» в СССР достигала $20-25$ \% населения. Этот класс обладал политическим весом, пользовался всеми выгодами. В высший разряд привилегированных Малевский-Малевич включал «влиятельных членов партии», «важных теоретиков марксизма», ученых, особенно принадлежавших к ядерной и электронной ветвям науки, народных артистов, «писателей-столпов режима», некоторых министров, особо стоящих высоких чиновников (например, председателя АН СССР). Второе по численности место, по мнению Малевского-Малевича, занимал класс сравнительно многочисленных «средних привилегированных». Общая их черта - принадлежность к интеллектуальным кругам и профессиям. Верхний слой этого класса - профессора университетов, писатели, чиновники различных государственных администраций высшего и среднего ранга, директора промышленных трестов и крупных заводов, директора наиболее значительных колхозов и совхозов. 
Малевский-Малевич отмечал, что «класс средних привилегированных» соприкасался с классом «привилегированных высшего разряда». Средний и низший слой этого класса образуют доктора, артисты, художники, архитекторы, инженеры, директора больших магазинов, второстепенные ученые и др. Они соответствуют средним и мелким буржуа развитых стран. Положение класса «привилегированных», писал С. Малевский-Малевич, улучшается, что соответствует кристаллизации новых классов советского общества. Класс «низших привилегированных», как отмечал МалевскийМалевич, в СССР самый многолюдный. Роль, которую он играл в СССР, велика. Это класс «надсмотрщиков - цепных собак коммунистической партии». К ним он относил явную или тайную полицию, мелких государственных чиновников, служащих книжных магазинов, газетных косков и пр. В. В. Белоцерковский, рассматривая особенности слоев, отмечал, что самым консервативным слоем являлись региональные партийные руководители, так как любая экономическая и политическая демократизация «угрожает их власти и привилегиям». Главный аргумент, которым доказывает автор свои взгляды, - активная роль регионального руководства в свержении Н. С. Хрущева [Белоцерковский, 1977, с. 54].

Характеристика «средних» классов советского общества выглядела довольно противоречиво. По мнению В. В. Сокирко, очень быстро обуржуазивался нижний слой элиты, руководители производства. Здесь автор видел опасность, так как, по его мнению, тенденции обуржуазивания «сверху» и «снизу» должны идти параллельно, в противном случае неизбежна «разрушительная революция». В то же время В. В. Сокирко со скепсисом относился к теории о ведущей роли интеллигенции, называл ее «плодом интеллигентского самообольщения». По его мнению, интеллигенция очень малочисленна и разношерстна, чтобы стать решающей силой. Она способна лишь подорвать устойчивость общества и нарушить эволюционный ход развития [Буржуадемов, 1974, с. 182]. В. Белоцерковский также считал, что научная интеллигенция - слой достаточно пассивный, а гуманитарная интеллигенция, кроме пассивности, отличается лицемерием (в этом В. Белоцерковский ссылался на мнение А. Д. Сахарова и А. А. Амальрика). К тому же у гуманитарной интеллигенции отсутствует чувство ответственности. Она отличается «народофобией», говорит о русском бунте, бессмысленном и беспощадном. Высокопоставленные же советники и эксперты от науки до реальной власти не допускаются, они слишком деморализованы «своими огромными материальными привилегиями» [Белоцерковский, 1977, с. 61].

Практически все упомянутые выше авторы работ о социальной структуре СССР дали свои характеристики «низшим» группам советского обще- 
ства. По мнению В. В. Сокирко, в низах общества «постоянно рождается класс-буржуа», такой класс появляется среди рабочих («рабочая аристократия») с жаждой повышенного заработка, которая все больше втягивает их в «капиталистическую потогонку». Проявлением обуржуазивания рабочих В. В. Сокирко считает создание ими своих маленьких товарных хозяйств - дач [Буржуадемов, 1974, с. 172]. С. Малевский-Малевич характеризовал основную массу населения СССР (колхозников, совхозников, рабочих и мелких служащих) очень бегло, отметив, что они находятся в тяжелых материальных условиях, лишены всякой возможности защищаться [Малевский-Малевич, 1972, с. 35-42]. В. В. Белоцерковский подчеркнул, что крестьянство в политическом отношении представляется совершенно беспомощным. Более подробно этим автором был охарактеризован «услужающий слой», который, по мнению публициста, и представляет собой «народ». «Услужающий слой», как пишет В. В. Белоцерковский, весьма многочисленен, именно с ним и соприкасаются интеллигенты; слой этот больше всего деморализован и алкоголизирован, разобщен, развращен «новым классом» партийной олигархии. Существование «услужающего» слоя в условиях госкапитализма особенно пагубно, так как всякая инициатива невозможна. По мнению В. Белоцерковского, «услужающему» слою способен противостоять мощный инженерно-рабочий слой («заводской народ»). Однако, отмечал В. Белоцерковский, специфика госкапитализма такова, что отсутствует жесткая конкуренция между людьми. В. Белоцерковский обращал внимание на близость заводской интеллигенции и рабочих (по происхождению, по бытовым и материальным условиям). Наибольшее недовольство, по мнению В. Белоцерковского, присутствует у инженеров, так как на них приходится самый сильный в стране административный нажим. Инженеры, в свою очередь, радикализируют рабочих. Таким образом, делает вывод Белоцерковский, в условиях «тоталитарного государственного капитализма» сложился особый монолитный социальный слой инженеров, техников и рабочих промышленности. Этот слой более других заинтересован в глубоких и преемственных изменениях социально-экономической структуры и более других к ней подготовлен [Белоцерковский, 1977, c. 87].

\section{4. Выводы}

Таким образом, в 1950-1970-е годы в Русском Зарубежье шла активная мыслительная работа, направленная на анализ социальных сил советского общества. Она началась в период, когда в СССР шли активные процессы общественной трансформации, возникали новые социальные груп- 
пы. Однако внутренняя ситуация в советской науке не давала возможности проанализировать начавшиеся сдвиги, поскольку положение Конституции СССР об основных классах советского общества оставалось неизменным. В то же время эмигранты из СССР активно изучали социальные процессы в стране, предлагали свои объяснительные схемы, подчас очень оригинальные, интересные и полезные для современного гуманитарного знания.

Нельзя не отметить, конечно, идеологическую предвзятость ряда работ, что неудивительно: многие исследователи Русского Зарубежья были настроены антисоветски, о чем свидетельствовал и их жизненный путь. При этом, несмотря на различие высказанных взглядов, практически все исследователи в Русском Зарубежье отмечали дифференциацию советского послевоенного общества, формирование разнородных слоев и групп, исповедовавших разные интересы (высшего слоя, представленного разного рода руководителями и управленцами, партийными функционерами; среднего слоя, включавшего в себя прежде всего интеллигенцию, и низших слоев, представленных трудящимися классами - рабочими, колхозниками). Наиболее перспективным с точки зрения продвижения «наверх» большинству авторов (Г. Ф. Ахминов, А. А. Амальрик, В. В. Белоцерковский и др.) казался «средний слой» - для одних это была интеллигенция или «специалисты», другие делали упор на прогрессивную роль инженеров и рабочих. Г. Ф. Ахминов считал, что идеология «среднего слоя» начинает складываться сразу после Великой Отечественной войны, этот класс, по его мнению, стремился к захвату власти. Однако Г. Ф. Ахминов, а также В. В. Белоцерковский настаивали на том, что не вся интеллигенция прогрессивна, а только та ее часть, которая непосредственно связана с материальным производством (прежде всего инженерно-техническая и экономическая). А. А. Амальрик был настроен в отношении среднего класса более пессимистично, отмечая его «развращенность» режимом. Практически единогласным мнением представителей Русского Зарубежья была мысль о существовании привилегированного высшего класса, который держится за власть, оказывает давление на прогрессивные слои, но сам является довольно консервативным. В то же время и он, по мнению многих исследователей, не был свободен он радикальных изменений, связанных с процессами продвижения капитализма.

Особое внимание в этом смысле обращалось на региональное партийное руководство и его противостояние центральному партийному руководству, в том числе Первому секретарю ЦК КПСС (позднее - Генеральному секретарю ЦК КПСС). Ряд исследователей (особенно В. В. Сокирко) акцентировали внимание на складывании прогрессивных взглядов в высшем пар- 
тийном руководстве, с чем он связывал надежды на возможность реформирования страны. Что касается низших классов в советском обществе, практически все исследователи отмечали их бесправие, тяжелое материальное положения, внутреннее недовольство режимом, которое все же не перерастало в открытое противостояние. Наибольшие надежды на участие в возможных изменениях вызывали рабочие («заводской народ», как его называл В. В. Белоцерковский), которые реагировали на мнение инженерно-техническое слоя и были близки к нему. В целом интеллектуальная деятельность представителей Русского Зарубежья создала хорошую отправную точку для размышлений о социальных силах советского общества, движущих мотивах их деятельности и борьбе за место в классовой иерархии.

\section{Источники}

1. Авторханов A. Мемуары / А. Авторханов. - Possev-Verlag, 1983. - 770 c.

2. Авторханов A. Технология власти : Процесс образования КПСС (Мемуарноисторические очерки) / А. Авторханов. - Мюнхен : ЦОПЭ, 1959. - 418 с.

3. Амальрик А. А. Просуществует ли Советский Союз до 1984 года? / А. А. Амальрик. - Амстердам : фонд имени Герцена, 1969. - 76 с.

4. Архив Российской Академии наук. Санкт-Петербургский филиал. Ф. 225. Оп. 004а. Д. 96.

5. Ахминов Г. Ф. Объективное сопротивление в СССР / Г. Ф. Ахминов. - Мюнхен : Институт по изучению СССР, 1956. - 104 с.

6. Белоцерковский В. Свобода, власть и собственность / В. Белоцерковский. - Западная Германия, Ахберг : Издательство Ахберг, 1977. — 183 с.

7. Билимович А. Д. Эра пятилетних планов в хозяйстве СССР : в 2-х ч. / А. Д. Билимович. - Мюнхен : Институт по изучению СССР, 1959.

8. Буржуадемов К. Очерки растущей идеологии / К. Буржуадемов. - Мюнхен : Эхо, 1974. - $271 \mathrm{c}$.

9. Бург Д. Оппозиционные настроения молодежи в годы после оттепели / Д. Бург. Мюнхен : ЦОПЭ, 1960. - 64 с.

10. Вознесенский Н. Военная экономика СССР в период Отечественной войны / Н. Вознесенский. - Москва : ОГИЗ, 1947. — 192 с.

11. Кованьковский П. А. Бюджет СССР : историко-критический обзор / П. А. Кованьковский. - Мюнхен : Институт по изучению СССР, 1956. - 152 с.

12. Криптон К. Осада Ленинграда / К. Криптон. - Нью-Йорк : Издательство имени Чехова, 1952. - $254 \mathrm{c}$.

13. Летопись Севера. - Москва : Географгиз, 1957. — Т. 2. - 282 с.

14. Малевский-Малевич С. СССР сегодня и завтра / С. Малевский-Малевич. - Париж : [б. и.], 1972. - $184 \mathrm{c.}$

15. Марченко В. П. Основные черты хозяйства послесталинской эпохи / В. П. Марченко. - Мюнхен : Институт по изучению СССР, 1959. — 96 с.

16. Молодежь Советского Союза. XIV конференция Института по изучению СССР (Мюнхен, 5-6 ноября 1962 г.). — Мюнхен : Институт по изучению СССР, 1962. $159 \mathrm{c}$. 
17. Российский государственный архив новейшей истории (РГАНИ). Ф. 5. ОП. 55. Д. 57. Лл. $32-43$.

18. Сербин Е. Политические настроения в советской армии в послесталинский период / Е. Сербин. - Мюнхен : Институт по изучении СССР, 1956. - 87 с.

19. Филиппов А. П. Научный социализм и наука об обществе / А. П. Филиппов. Мюнхен : Институт по изучению СССР, 1955. - 159 с.

20. Х конференция Института по изучению СССР (Мюнхен, 25-26 июля 1958 г.). Современное советское общество. - Мюнхен : Институт по изучению СССР, 1958. - 167 с.

\section{ЛИТЕРАТУРА}

1. Александров К. М. Офицерский корпус армии генерал-лейтенанта А. А. Власова / К. М. Александров. - Санкт-Петербург : Русско-Балтийский ИЦ Блиц, 2001. - 359 с.

2. Бузукашвили М. Николай Троицкий. Удивительная история жизни и борьбы / М. Бузукашвили // Знак вопроса. - 2012. - № 3. - С. 31-37.

3. Восленский М. С. Номенклатура / М. С. Восленский. - Москва : Издательский дом «Советская Россия» совм. С МП «Октябрь», 1991. - 624 с.

4. Джилас М. Новый класс / М. Джилас. - Нью-Йорк : Издательство Фридерик А. Прегер, 1957. - 248 с.

5. Егоров Ю. Н. Эволюция российской экономической науки в работах представителей Русского Зарубежья / Ю. Н. Егоров. - Москва : Риалтекс, 2009а. — 243 с.

6. Егоров Ю. Н. Экономические взгляды ученых русского зарубежья в послевоенные годы / Ю. Н. Егоров // Вестник экономической интеграции. — 2009б. — № 1. C. $3-7$.

7. Кодин E. В. Николай Троицкий : от симбирского повстанца до директора Мюнхенского института по изучению СССР / Е. В. Кодин // Новый исторический вестник. 2013. — № 37. — С. 148-167.

8. Константинов Д. В. (протоиерей). «Вторая волна»- воспоминания и раздумья о российской эмиграции / Д. В. Константинов // В поисках истины : Пути и судьбы второй эмиграции. - Москва : РГГУ, 1997. — С. 56-85.

9. Константинов Д. В. Мюнхенский институт (из истории второй российской политической эмиграции) / Д. В. Константинов // Голос зарубежья. — 1983. — № 29. C. $13-21$.

10. Константинов Д. В. Мюнхенский институт. Из истории второй российской политической эмиграции / Д. В. Константинов // Трибуна русской мысли. — 2002. № 4. - C. $133-144$.

11. Островский В. Б. Колхозное крестьянство СССР : Политика партии в деревне и ее социально-экономические результаты / В. Б. Островский. - Саратов : Издательство Саратовского университета, 1967. - 329 с.

12. Parry A. The new class divided: Science and technology versus communism / A. Parry. — New York : Macmillan ; London : Collier — Macmillan, Cop. 1966. — 364 c.

13. Попов A. B. Мюнхенский институт по изучению истории и культуры СССР и «вторая волна эмиграции» / А. В. Попов // Новый исторический вестник. - 2004. № 10. - С. $54-71$.

14. Рабочий класс СССР и его ведущая роль в строительстве коммунизма. - Москва : Наука, 1975. - 568 с. 
15. Сенявский С. Л. Рост рабочего класса СССР. (1951-1965 гг.) / С. Л. Сенявский. - Москва : Наука, 1966. - 279 с.

16. Толстой И. О чем рассказал загадочный Криптон (Забытая книга о блокаде) [Электронный ресурс] / И. Толстой. - Режим доступа : http://www.svoboda.org/content/ article/25244051.html

17. Ярославский Е. М. О роли интеллигенции в СССР / Е. М. Ярославский. - Москва : Государственное издательство политической литературы, 1939. - 39 с.

18. Matthews M. Class and society in Soviet Russia / M. Matthews. — New York : Walker, 1972. - $366 \mathrm{p}$.

19. Matthews M. Poverty in the Soviet Union : the Life-Styles of the Underprivileged in Recent Years / M. Matthews. — New York : Cambridge University Press, 1986. — 227 p.

20. Matthews M. Privilege in the Soviet Union : a Study if Elite Life-Styles under Communism / M. Matthews. — London ; Boston ; Sydney : Allen \& Unwin, 1978. - 196 p.

21. Назаров М. Миссия русской эмиграции / М. Назаров. - Ставрополь : Кавказский край, 1992. - Т. 1. - 414 с.

22. O'Connel Ch. T. The Munich Institute for the Study of the USSR / Ch. T. O'Connel. Pittsburgh : Univ. of Pittsburgh center for Russ. and East Europ. Studies, 1990. — 46 p.

23. Voslenskii M. S. Nomenklatura: the Soviet ruling class / M. S. Voslenskii. — New York, Garden City : Doubleday, 1984. — 455 p.

\section{Problem of Social Leadership and Social Conflict in USSR in Works of Scientists of Russian Emigre of 1950s ANd 1970s ${ }^{1}$}

(C) Tatyana M. Dimoni (2020), orcid.org/0000-0002-9049-1469, ResearcherID AAF-46382019, SPIN 4394-1937, Doctor of History, associate professor, Vologda State University (Vologda, Russia), dimonitm@yandex.ru.

The issue of understanding by scientists and public figures of the Russian Emigre of social relations in the USSR of the 1950-1970s is considered in the article. The novelty of the work lies in the choice of sources of research - articles and books of figures of Russian Emigre. The author emphasizes that the main part of the ideas of the considered authors is not sufficiently represented in the scientific community. It is noted that the founders of the research of Soviet society were scientists from the Munich Institute for the Study of History and Culture of the USSR, which in 1957 held a major international conference "Modern Soviet Society". It is concluded that the conference reports on the multiplicity of Soviet society, the presence of serious legal and economic differentiation, the emergence of new progressive classes (engineering and technical intelligentsia) laid the foundation for promoting research on Russian society. According to the author, in the late 1960s, this direction was actively cultivated by Soviet dissidents who emigrated to the West, and close associates who remained in the USSR (A. A. Amalrik, K. Bourzhuademov, S. S. Malevsky-Malevich, V. Belotserkovsky). A review of the historiography of the Russian Emigre allows us to create a platform for reflection on the social forces of Soviet society, the driving motives of their activity and the struggle for a place in the class hierarchy.

Key words: USSR; Russian Emigre; class conflict; class leadership.

1 The study was carried out with the financial support of the Russian Foundation for Basic Research, project 18-09-00184 "Social revolution in Soviet Russia: prerequisites, stages, results". 


\section{Material Resources}

Akhminov, G. F. (1956). Obektivnoye soprotivleniye v SSSR. Myunkhen: Institut po izucheniyu SSSR. (In Russ.).

Amalrik, A. A. (1969). Prosushchestvuet li Sovetskiy Soyuz do 1984 goda? Amsterdam: fond imeni Gertsena. (In Russ.).

Arkhiv Rossiyskoy Akademii nauk. Sankt-Peterburgskiy filial. F. 225. Op. 004a. D. 96. (In Russ.).

Avtorkhanov, A. (1959). Tekhnologiya vlasti: Protsess obrazovaniya KPSS (Memuarno-istoricheskiye ocherki). Myunkhen: TsOPE. (In Russ.).

Belotserkovskiy, V. (1977). Svoboda, vlast'i sobstvennost'. Zapadnaya Germaniya, Akhberg: Izdatelstvo Akhberg. (In Russ.).

Bilimovich, A. D. (1959). Era pyatiletnikh planov v khozyaystve SSSR. Myunkhen: Institut po izucheniyu SSSR. (In Russ.).

Burg, D. (1960). Oppozitsionnyye nastroyeniya molodezhi v gody posle ottepeli. Myunkhen: TsOPE. (In Russ.).

Burzhuademov, K. (1974). Ocherki rastushchey ideologii. Myunkhen: Ekho. (In Russ.).

Dzhilas, M. (1957). Novyy klass. Nyu-York: Izdatelstvo Friderik A. Preger. (In Russ.).

Filippov, A. P. (1955). Nauchnyy sotsializm i nauka ob obshchestve. Myunkhen: Institut po izucheniyu SSSR. (In Russ.).

Kovankovskiy, P. A. (1956). Byudzhet SSSR: istoriko-kriticheskiy obzor. Myunkhen: Institut po izucheniyu SSSR. (In Russ.).

Kripton, K. (1952). Osada Leningrada. Nyu-York: Izdatelstvo imeni Chekhova. (In Russ.).

Letopis'Severa, 2. (1957). Moskva: Geografgiz. (In Russ.).

Malevskiy-Malevich, S. (1972). SSSR segodnya i zavtra. Parizh: [b. i.]. (In Russ.).

Matthews, M. (1972). Class and society in Soviet Russia. New York: Walker.

Matthews, M. (1986). Poverty in the Soviet Union: the Life-Styles of the Underprivileged in Recent Years. New York: Cambridge University Press.

Matthews, M. (1978). Privilege in the Soviet Union: a Study if Elite Life-Styles under Communism. London; Boston; Sydney: Allen \& Unwin.

Marchenko, V. P. (1959). Osnovnyye cherty khozyaystva poslestalinskoy epokhi. Myunkhen: Institut po izucheniyu SSSR. (In Russ.).

Molodezh' Sovetskogo Soyuza. XIV konferentsiya Instituta po izucheniyu SSSR (Myunkhen, 5-6 noyabrya 1962 g.). (1962). Myunkhen: Institut po izucheniyu SSSR. (In Russ.).

Rossiyskiy gosudarstvennyy arkhiv noveyshey istorii (RGANI). F. 5. Op. 55. D. 57. L1. 32 - 43. (In Russ.).

Serbin, E. (1956). Politicheskiye nastroyeniya $v$ sovetskoy armii v poslestalinskiy period. Myunkhen: Institut po izuchenii SSSR. (In Russ.).

Voznesenskiy, N. (1948). Voyennaya ekonomika SSSR v period Otechestvennoy voyny. Moskva: Gospolitizdat. (In Russ.).

X konferentsiya Instituta po izucheniyu SSSR (Myunkhen, 25-26 iyulya 1958 g.). Sovremennoye sovetskoye obshchestvo. (1958). Myunkhen: Institut po izucheniyu SSSR. (In Russ.).

\section{REFERENCES}

Avtorkhanov, A. (1983). Memuary. Possev-Verlag. (In Russ.). 
Aleksandrov, K. M. (2001). Ofitserskiy korpus armii general-leytenanta A. A. Vlasova. SanktPeterburg: Russko-Baltiyskiy ITs Blits. (In Russ.).

Buzukashvili, M. (2012). Nikolay Troitskiy. Udivitelnaya istoriya zhizni i borby. Znak voprosa, 3: 31-37. (In Russ.).

Egorov, Yu. N. (2009a). Evolyutsiya rossiyskoy ekonomicheskoy nauki v rabotakh predstaviteley Russkogo Zarubezhya. Moskva: Rialteks. (In Russ.).

Egorov, Yu. N. (2009b). Ekonomicheskiye vzglyady uchenykh russkogo zarubezhya v poslevoyennye gody. Vestnik ekonomicheskoy integratsii, 1: 3-7. (In Russ.).

Kodin, E. V. (2013). Nikolay Troitskiy: ot simbirskogo povstantsa do direktora Myunkhenskogo instituta po izucheniyu SSSR. Novyy istoricheskiy vestnik, 37: 148-167. (In Russ.).

Konstantinov, D. V. (1983). Myunkhenskiy institut (iz istorii vtoroy rossiyskoy politicheskoy emigratsii). Golos zarubezhya, 29: 13-21. (In Russ.).

Konstantinov, D. V. (1997). (protoiyerey). «Vtoraya volna» — vospominaniya i razdumya o rossiyskoy emigratsii. V poiskakh istiny: Puti i sudby vtoroy emigratsii. Moskva: RGGU. 56-85. (In Russ.).

Konstantinov, D. V. (2002). Myunkhenskiy institut. Iz istorii vtoroy rossiyskoy politicheskoy emigratsii. Tribuna russkoy mysli, 4: 133-144. (In Russ.).

Nazarov, M. (1992). Missiya russkoy emigratsii, 1. Stavropol': Kavkazskiy kray. (In Russ.).

O'Connel, Ch. T. (1990). The Munich Institute for the Study of the USSR. Pittsburgh: Univ. of Pittsburgh center for Russ. and East Europ. Studies.

Ostrovskiy, V. B. (1967). Kolkhoznoye krestyanstvo SSSR: Politika partii v derevne i yeye sotsialno-ekonomicheskiye rezultaty. Saratov: Izdatelstvo Saratovskogo universiteta. (In Russ.).

Parry, A. (1966). The new class divided: Science and technology versus communism. New York: Macmillan; London: Collier - Macmillan, Cop.

Popov, A. V. (2004). Myunkhenskiy institut po izucheniyu istorii i kultury SSSR i «vtoraya volna emigratsii». Novyy istoricheskiy vestnik, 10: 54-71. (In Russ.).

Rabochiy klass SSSR iyego vedushchaya rol'v stroitelstve kommunizma. (1975). Moskva: Nauka. (In Russ.).

Senyavskiy, S. L. (1966). Rost rabochego klassa SSSR. (1951-1965 gg.). Moskva: Nauka. (In Russ.).

Tolstoy, I. O chem rasskazal zagadochnyy Kripton (Zabytaya kniga o blokade). Available at: http://www.svoboda.org/content/article/25244051.html/.

Voslenskii, M. S. (1984). Nomenklatura: the Soviet ruling class. New York, Garden City: Doubleday.

Voslenskiy, M. S. (1991). Nomenklatura. Moskva: Sovetskaya Rossiya ; Oktyabr'. (In Russ.). Yaroslavskiy, E. M. (1939). O roli intelligentsii v SSSR. Moskva: Gosudarstvennoye izdatelstvo politicheskoy literatury. (In Russ.). 